\title{
Handlingsplan mot selvmord - hva viser evalueringen?
}

\author{
Ved I rene Sørås
}

Arbeidet med evaluering av Handlingsplan mot selvmord er nå sluttført. Evalueringen har pågått siden handlingsplanen ble iverksatt høsten 1994, og er utført av Agenda Utredning \& Utvikling AS. Irene Sørås har ledet evalueringen, og skriver i denne artikkelen om hovedfunnene fra evalueringen.

$\mathrm{H}$ andlingsplan mot selvmord ble avsluttet ved utgangen av 1999 etter seks års "virketid". I tråd med god styringsfilosofi er handlingsplanen blitt evaluert både underveis med fortløpende tilbakemeldinger til $\mathrm{H}$ elsetilsynet og $\mathrm{i}$ form av en endelig resultatevaluering. På den måten har $\mathrm{H}$ elsetilsynet åpnet for læring og justering av strategier underveis. En oppsummerende sluttrapport viser hva som er oppnådd i regi av $\mathrm{H}$ andlingsplan mot selvmord. ( $A$ gen da 2000)

\section{Hva er evaluert?}

I en evaluering av $\mathrm{H}$ andlingsplan mot selvmord vil nok de fleste forvente at evalueringen skal si noe om eventuelle effekter av handl ingsplanen på selvmordshyppigheten i befolkningen eller grupper det har vært rettet spesiell innsats mot. $H$ va har handlingsplanen betydd for selvmordstruede mennesker? Til tross for at det overordnede målet med handlingsplanen nettopp har vært at "helsetjenesten skal bidra til å redusere sel vmordshyppigheten i N orge", har det ikke vært mandatet for evalueringen å finne ut hvorvidt eller eventuelt hvordan dette har skjedd. Evalueringen har derimot hatt som mandat å vurdere i hvilken grad de fire første delmålene i handlingsplanen er oppnådd. Delmålene har vært:

\section{$\AA$ etablere et nasjonalt og tre} regionale ressursmiljøer

\section{A stimulere til økt og systematisk} forskning

\section{Å få til systematisk kunnskaps-} formidling

\section{A drive informasjonsvirksomhet}

$\AA$ få til systematiske modellforsøk med behandlingstiltak og oppfølgingstiltak

Det siste delmål et er evaluert separat av handlingsplanens prosjektleder $\mathrm{N}$ ils Petter Reinholdt (2000) og omtales derfor ikke her.

I tillegg til måloppnåelsen har evalueringen konsentrert seg om iverksettingen av $\mathrm{H}$ andlingsplan mot selvmord og hvilke strategier som er brukt underveis.

\section{Hva er oppnådd ?}

Rent generelt kan vi konkludere med at de fire delmålene i $\mathrm{H}$ andlingsplan mot selvmord som omfattes av evalueringen, langt på veg er oppnådd. Etableringen av ressursmiljøene kom i gang, om enn på ulike tidspunkt: Det nasjonale senteret, Seksjon for selvmordsforskning og -forebygging (SSFF), var først ute, dernest ble det etablert regionale sentra i Bergen, Trondheim og Tromsø. Til tross for at de fire sentrene har utviklet seg noe forskjellig, har vi funnet at de utfyller hverandre på mange måter, både $\mathrm{i}$ form og innhold. A ktivitetsnivået ved

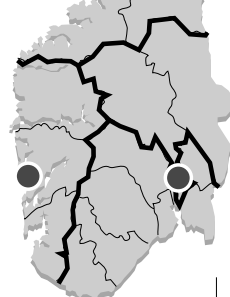
sentrene har stort sett vært høyt og målrettet, til tross for en noe famlende start ved de regionale sentrene.

Gjennom evalueringen har vi konstatert at handlingsplanen både har utløst $ø k t$ forskning, og at forskningen har fått en større tematisk bredde. I perioden før handlingsplanen (1990-93) eksisterte det ca 10 suicidologiske forskningsprosjekter av en viss størrelse med ca 20 forskere involvert, mens det i perioden 1997-2000 er hele 33 forskningsprosjekter av tilsvarende størrelse, og nå med hele 47 forskere involvert. D et har samtidig skjedd en viss dreining i tematikk fra tidligere generelle epidemologiske undersøkelser med psykiatrisk forankring til prosjekter innenfor mange ulike arenaer, som for eksempel evaluering av effekter av behandlingstiltak. Spesielt forskning på selvmord blant barn og unge har etter hvert fått en viktig plass. Forskernes faglige bakgrunn viser seg å ha fătt større bredde og omfatter i dag disipliner som psykologi, pedagogikk, sosiologi, historie og sykepleie, foruten psykiatri. Det er også verdt å merke seg at det er oppnådd økt samarbeid mellom forskningsmiljøer. H er har ressursmiljøene, særlig SSFF og ressursmiljøet i Bergen, spilt en viktig rolle ved å etablere egne forskningsfora.
Det er også oppløftende at $\mathrm{N}$ orge nå markerer seg atskillig sterkere internasjonalt enn før handlingsplanens inntreden. Flere norske forskere deltar i internasjonale samarbeidsprosjekter og bidrar med større antall presentasjoner på internasjonale kongresser, for eksempel den som IA SP (International A ssociation for Suicide Prevention) avholder.

Et av de andre sentrale delmålene har vært å drive kunnskapsformidling om suicidologi. De første årene (1994-96) holdt fylkeslegene kurs for aktuelle yrkesgrupper. Resultatet var at ca 10000 fagpersoner gjennomgikk kurs innen suicidol ogi. Strategien som senere ble valgt, har vært både å utvikle læremateriell og undervisningsopplegg for grunn-, videreog etterutdanning innen relevante faggrupper som kommer i kontakt med selvmordstruede. A rbeidet med kunnskapsformidlingen har vi konkludert med har langt på veg vært vellykket, men ressurskrevende.

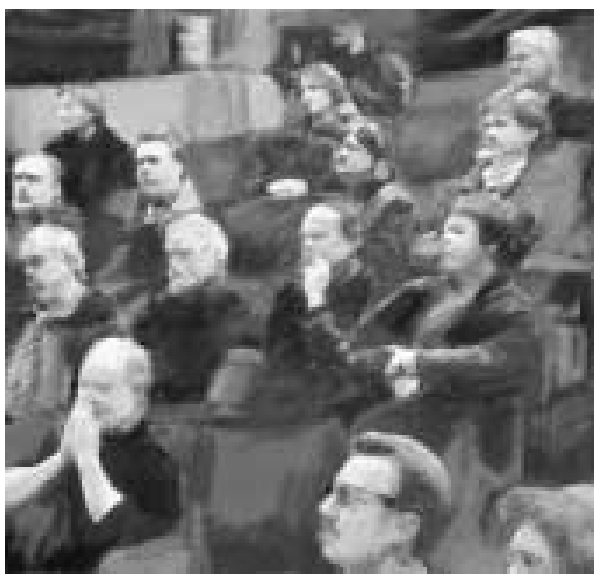

Særlig er det blitt utarbeidet gode læremidler og undervisningsopplegg både for høgskoler og universitetene. Det er drevet et aktivt påvirkningsarbeid for å få høgskolene og universitetene til å ta suicidologi inn i læreplaner. Evalueringen konkluderer med at arbeidet har kommet relativt langt både på medisin- og psykologistudiet, og på enkel te høgskoler innen lærer-, sykepleie- og sosionomutdanningen. 


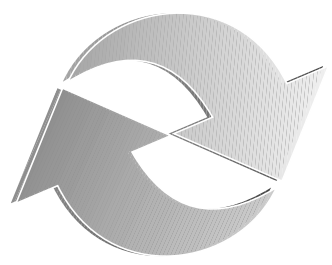

D ette arbei det har imidlertid synliggjort en viktig erfaring: $\AA$ ha som ambisjon à få et hel sefaglig tema inn i Iæreplaner på høgskoler og universiteter, byr på store utfordringer. I og med at Iæreinstitusjonenes autonomi omfatter full styring over egne lære- og fagplaner, har arbeidet med å få suicidologi inn i undervisningen måttet rette seg mot den enkelte læreinstitusjon. D ette har vært svært ressurskrevende, men heller gitt et beskjedent resultat sett i forhold til innsatsen. M uligens hadde arbeidet glidd noe lettere ved interdepartementalt påtrykk fra SH D/ $\mathrm{H}$ el setilsynet overfor Kirke-, undervisnings- og forskningsdepartementet.

"LivingW orks" er betegnel sen på et, opprinnelig kanadisk, intervensjonskurs for personer som arbeider med selvmordstruede, og det er viet spesiell oppmerksomhet i evalueringen. 0 pplegget er en egen metode både for håndtering av selvmordstruede og for kunnskapsspredning på et vanskelig fagfelt.

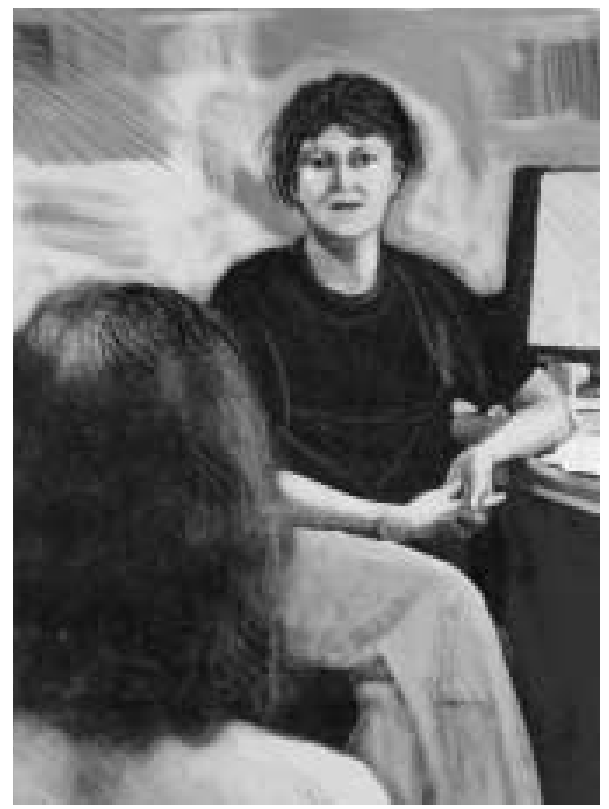

Vi konkluderer med at Living W orksopplegget har en god pedagogisk oppbygging og egner seg godt som et 'førstehjelpskurs' for mange yrkesgrupper. Kurset kommer også meget godt ut basert på deltakernes egne vurderinger. O pplegget er dessuten kostnadseffektivt ved at det stadig sertifiseres nye kursledere, og at stadig flere dermed kan benyttes til å spre kursopplegget.
Det siste delmålet i H andlingsplan mot selvmord, informasjonsvirksomheten, kommer særdeles heldig ut med hensyn til resultatoppnåelse. Selv om det er drevet mye informasjonsvirksomhet fra de regionale sentrene, er det SSFF som har hatt hånd om den nasjonale informasjonsstrategien. Informasjonsarbeidet har vært preget et høyt faglig nivå og av stor bredde i virkemidler: Internettpresentasjon med beskrivelse av $\mathrm{H}$ andlingsplan mot selvmord og aktivitetene i regi av den, informasjon om kurs- og konferansevirksomhet og forskningsvirksomhet. En egen krisehjelp er også lagt ut. En annen informasjonskanal er utarbeidel se og distribusjon av brosjyrer, mens en tredje kanal har vært å bruke media. Den siste kanalen har vært utgivel se av det dette tidsskriftet, som nå har et opplagstall på ca 5500 eksemplarer og utgis tre ganger årlig.

\section{Noen erfaringer}

$\AA$ iverksette et politisk satsingsområde i form av en handlingsplan kan gjøres på mange måter. I H andlingsplan mot selvmord er det to grep vi vil framheve som særlig vellykkete:

1) $\AA$ ha utarbeidet et godt plandokument, en prosjektplan, som har vært en reell ledetråd $\mathrm{i}$ arbeidet

2) å få etablert ressursmiljøene som har kunnet stå for gjennomføringen av de store oppgavene både nasjonalt og ute i regionene.

Samtidig ser vi betydningen av at når slike sentra bygges opp, kan de trenge drahjelp og aktiv støtte i en grad som det ikke er naturlig eller mulig for $\mathrm{H}$ elsetilsynet eller andre sentrale myndigheter å bistå med. Til tross for disse oppstartsproblemene, vurderer vi $\mathrm{H}$ andlingsplan mot selvmord som et vellykket foretak både fra $\mathrm{H}$ el setilsynets side og ikke minst sett i forhold til det som er oppnådd av resultater ved det nasjonale og de regionale sentrene.

\section{Litteratur}

A genda $U$ tredning $\& U$ tvikling. Evaluering av $\mathrm{H}$ andlingsplan mot selvmord. Sluttrapport 2000.

Reinholdt, $\mathrm{N}$ ils Petter: $\mathbf{H}$ andlingsplan mot selvmord. Sluttrapport fra evalueringen. Statens helsetilsyn 2000. 